удк 005.7(477)

A. Ostapenko, PhD student Taras Shevchenko National University of Kyiv, Kyiv, Ukraine

\title{
ORGANIZATIONAL-PEDAGOGICAL ACTIVITY OF I. P. LVOV
}

\section{Article described the activities of I. P. Lvov as the head of the department of pedagogy of the Chernigov Pedagogical Institute.} It were studied the handwritten labor of a teacher in conducting state examinations, analyzed the annual reports of the Department of Pedagogy, compiled by I. P. Lvov during the 1950-1951,1951-1952,1952-1953 school year, the plans of the department and the lesson plan with students of the 2nd year, Ukrainian and Russian departments of the Faculty of Humanities.

A personal qualities of the teacher were analyzed in the several archival documents. It showed that I. P. Lvov was a wise teacher and morally honest to students and colleagues, intellectually creative to support the department of pedagogy, as well as the laboratory of psychology with it with all the necessary equipment for students' independent education. He was quick-witted, presented innovative pedagogical ideas and introduced them into the pedagogical process of the department of pedagogy.

I. P. Lvov took the initiative to realization educational activities among students such as reports, lectures on the plans of public education authorities, school education authorities, school administration, parental committees and leadership of pedagogical circles.

I. P. Lvov considered it necessary that teachers of the institute read popular lectures to parents of students and thereby pedagogue them. Students of the institute were supposed to get involved in the work of class teachers, to carry out various types of classroom and extracurricular activities with pupils.

Report on the educational and methodical work of the Department of Pedagogy was analyzed At the Department of Pedagogy under the leadership of I. P. Lvov, working curricula for all disciplines of the department were heard in due time at regular meetings. I. P. Lvov in the report indicated positive moments about the educational activities carried out during the school year by teachers of the department of pedagogy to change the working plans of the department.

Keywords: I. P. Lvov, work plan for classes, work plan of the department of pedagogics, annual report

Formulation of the problem. Modern pedagogical science is drew ideas and scientific views from the heritage of Ukraine teachers of the past. Their acquisition for present researchers are great value. It is important not to forget the names of the figures who promoted to the development of pedagogy. Today, the pedagogical heritage of I. P. Lvov is still not completely studied in all aspects.I. P. Lvov is a not popular figure in Ukraine pedagogy. Only a few scientists (A. B. Borovik, N. M. Kuzmenko, A. K. Pronikov) found scientific interest to the personality of I. P. Lvov and briefly described his life, teaching and organizational activities as head of the department and head of teaching practice students.

The research objective is to analyze the organizational and pedagogical activity of I.P.Lvov in the post of head of the department of pedagogy. It is necessary to solve the following tasks: to describe the features of organizational and pedagogical activity of associate professor I. P. Lvov as head of the department of pedagogy, to focus his main ideas on education reform and development of the department of pedagogy in Chernihiv Teachers Institute, Chernigov Pedagogical Institute.

Research presentation. In the state archives of Chernihiv region 115 are stored archival materials, including the autobiography of I. P. Lvov, which indicates that he was born and raised in the town Yuryevka, he received higher education in the Kazan theological academy and he became a lecturer of pedagogy in the Chernigov theological seminary. I. P. Lvov after Seminary he worked at the pedagogical Institute. An Institute has several times changed its name, namely: the Institute of social education, pedagogical Institute, pedagogical Institute. During scientific-pedagogical and organizational activities in the Chernihiv pedagogical Institute I. P. Lvov showed himself as a wise lecturer, he was morally honest to students and colleagues, intellectual and creative to supply the department of pedagogy and psychology laboratory with all necessary equipment for self-training students. He was a smart, gave innovative pedagogical ideas and implements them in pedagogical process of the department of pedagogy. Despite the personal qualities and achievements I. P. Lviv, the Academic Council of Chernihiv pedagogical Institute recommended him for the position of head of the department of pedagogy.

I. P. Lviv was answered for training materials department and laboratory of psychology in it, he worked hard to ensure the department was fully complete with appropriate equipment and teaching materials for teachers and students.

I. P. Lvov, with the aim of improving qualifications, proposed realization seminars on the study of the higher nervous system with academician I. M. Pavlov together with the department of physical training.

Scientific work I. P. Lvov spared special attention. He stressed the need to attract students and teachers to scientific, methodological reports (conferences, seminars, round tables).

I. P. Lvov came up with an initiative to hold socially important work by lecturers: educational activities among students (reports, lectures on the plans of public educational administration, school educational administration, school administration, parent-teachers' association) and leadership pedagogical study group [12].

I. P. Lvov took care of the proper preparation of the department of pedagogy for the academic year (1949-1950) and the correction of defects, which were indicated by the commission for examining the work of the department.

It would not be unnecessary to add that I. P. Lvov intended to take a separate room for conducting psychological experiments. But it were failed for unknown reasons.

I. P. Lvov also regarded it necessary for the teachers of the institute to read popular lectures to the parents of the pupils and thereby they were like pedagogues. Students of the institute were supposed to get involved in the work of class teachers, to carry out various types of classroom and extracurricular activities with students [3].

According to I. P. Lvov, lecturers of the department of pedagogy should enrich their theoretical knowledge, help schools, and actively participated in scientific conferences. $\mathrm{He}$ also came out the accession of basic schools to institutions and stay on the budget of higher education institutions. Basic schools should become assistants and pedagogical laboratories [3].

Analyzing the results of the current monitoring of students' progress in pedagogy, I. P. Lvov noted that students understand important questions and answer them correctly. I. P. Lvov added in the report that some students did little to work on the lecture material, but they were better prepared independently for seminar tasks. Some students felt difficulties in introducing the doctrine of Academician I. P. Pavlov into pedagogy, since these questions were not sufficiently covered in educational literature [4]. 
Also I. P. Lvov analyzed that a small part of the students worked not systematically during the academic year, which was noticeable when viewing student notes in the notes; revealed the inability to use literature, it were logical to express their thoughts. Students lacked philosophical knowledge, poorly developed abstract thinking. Students learned school hygiene successfully, because the material was light and affordable. Pedagogical practice, students of the 2 nd course humanitarian faculty, they were held in the schools of the city of Chernigov, where they first got acquainted with the life and work of the school, received skills in educational and educational work.

Summing up the report, I. P. Lvov proposed to turn to the theory of classical teachers, to think over in detail the plan for the organic connection of the work of the department with the work of the school, to provide educational and methodological helps to the school and to adopt from it all the valuable things necessary for the education and training of teaching staff. I. P. Lvov proposed to develop a plan for the pedagogization of the institute and to control its work, created for this a commission from representatives of different departments. He also recommended to strictly regulate the order of mutual visits by teachers of the department of pedagogy and psychology of lectures, seminars [4]. I. P. Lvov advised teachers of psychology of schools of Chernigov, he visited their lessons, on the instructions of the Research Institute of Psychology of the Ukrainian SSR made an inspection of teaching psychology in schools № 7, studied the use of measures of encouragements and punishments by teachers of school № 6 of Chernigov [4].

At the Department of Pedagogy under the leadership of I. P. Lvov, a report on the educational and methodical work of the Department of Pedagogy was heard. Working curricula for all disciplines of the department were discussed in a timely manner at regular meetings [5]. I. P. Lvov in the report indicated statistical data on educational activities carried out during the school year by lecturers of the department of pedagogy and psychology to change the working plans of the department [5]. A minimum of literature was indicated for the development of topics for seminars, students wrote notes. Seminars were held in the form of questions from teachers and student responses. The activity of students in the classroom was small, a small number of students supported the discussion [5]. At the department of Pedagogy and Psychology under the leadership of I. P. Lvov, in the evening, they supported students in the form of group counseling, unscheduled individual counseling and review lectures on pedagogy, conducted for graduate students [5].

I. P. Lvov in the report noted that in all 12 groups of students of the russian language and literature department state exams were passed in pedagogy. I. P. Lvov was struck by the theoretical answers of graduate students in the course of pedagogy. Most students have carefully worked and studied the recommended literature and received positive marks in the exam. In the report, I. P. Lvov pointed out the negative aspects of the state exam, namely: some students knew the school's life and work superficially, they knew little about school documentation, students ' private matters, they didn't work out periodicals on teaching methods of teaching disciplines in schools, as well as pedagogical literature of the then period [5].

In the annual report about the work of the Department of Pedagogy of the Chernihiv Teachers' Institute for the 19511952 academic year I. P. Lvov, noted another activity of the department. At the Department of Pedagogy, a pedagogical circle was established, during the classes of which students could improve their knowledge, additionally learn about new discoveries in pedagogical science. archival documents were analyzed about of the pedagogical circle, in which students expressed a desire to take part in the work of the circle. Themes of the sessions were pedagogical. I. P. Lvov, one of the leaders of the group, at one of the meetings read the report "The Modern Tasks of the Reorganization of the Science of Psychology in the Worldview of Acad. I. P. Pavlova" [5].

I. P. Lvov separately described in the report (the name of the above). I. P. Lvov separately described in the report the work of the department assistant G. P. Svirida, conscientiously realized her duties, provided students with educational and recommended literature in the form of individual monographs, pedagogical magazines, newspapers, as well as visual aids in psychology, pedagogy and school hygiene [5].

A positive moment in the activities of the department, according to I. P. Lvov, was the timely organization of pedagogical exhibitions devoted to the life activity of A. S.Makarenko and national system of public education [5]. I. P. Lvov, to improve students' progress in psychology, recommended: to improve the quality of teaching anatomy and human physiology in the 8th grade; to improve the quality of teaching psychology and logic in secondary schools; to organize systematic help to students for independent work from the first day of study at the Chernihiv pedagogical Institute; to strengthen control over the students' independent work by systematically reviewing lecture notes, discussing them, and more often practice colloquiums, but not to the prejudice of students from other disciplines; not limited to traditional lecture or conversation; work on the book to carry out during the school year; in connection with student poor progres to report student organization; invite students to meetings of the department of pedagogy and psychology so that they report on their independent work; improve the living conditions of students; they often attend lectures by psychology teachers. From pedagogy: to attract more students to work at school; don't assign the seminar topics on the same day as other groups; for practical exercises in pedagogy, students should be allocated to several schools, rather than focusing on one school; it is necessary to increase the hours in the pedagogical practice of graduate students, this will allow enough time to make real plans and tasks for the pedagogical practice and prepare for speaking at school [5].

In the 1954-1955 academic year, I. P. Lvov approved at a meeting of the department a work plan for lessons from logic with students of the verbal and literary faculty (Ukrainian and Russian departments) of the 2nd year [7].

I. P. Lvov worked not only on new methods of pedagogy and psychology developed by him, but even from logic. A scientist proposed to study the logic of humanities in the following order:

1. The concept of thinking, knowledge of thinking and the value of practice.

2. The subject and meaning of logic, the difference between psychological and logical objects from the point of view of thinking, the subject of formal logic, laws and forms of thinking as a reflection of objective reality, formal and dialectical logic [6].

3. Logical laws, concepts, definitions of ideas, division of concepts, types of relationships between concepts: equivalent, cross-concepts, submissions, opposites, contradictions, subjectings, separation of judgments by content, separation of categorical judgments by quality [6].

In 1955, I. P. Lvov headed the commission for state exams of the correspondence department of the Russian language and literature, which included the following delegates: Russian literature teacher P. G. Mineev, Russian teacher. D. D. Odinets, teacher of pedagogy I. P. Kutsenko [1]. The report indicated that all graduate students completed the 
curriculum, they passed all tests and exams, the results are recorded in the relevant documentation, personal files are correct. Chernihiv Pedagogical Institute has created all the conditions for the normal realization of state examinations. Examinations were calm. According to the scientist I. P. Lvov, the results of state examinations in pedagogy [1] demonstrated that students mastered program material, most of the students answered correctly and with restraint to didactic questions, educational theories and showed their skills in practical use of theoretical knowledge [1].

I. P. Lvov had the task of analyzing and discussing the resolution of I. A. Kairov "On the state of pedagogical science and measures to eliminate its backwardness" at the Council of the Institute on Pedagogy. The teacher was very worried and responsibly treated to perform work on properly selected measures on the consequences of the backlog of teacher education. I. P. Lvov questioned the scientific decisions regarding general and polytechnic education in schools, noted that the forms and methods of teaching, age characteristics and the level of training of students are considered separately from each other.

After analyzing the resolution "On the state of pedagogical science and measures to eliminate its backlog," I. P. Lvov noted that it did not show the features of learning material acquired by schoolchildren, students, the low level of training of some scientific and pedagogical workers, and were not characterized. The gap between methods and didactics of teaching subjects, there is no scientific development of textbooks on polytechnic education, unrelated theory with practice in productive work and public works.

The resolution pointed out deficiencies in the scientific activities of the Academy of Pedagogical Sciences. I. P. Lvov, in his report (on the resolution), noted that the PSA had been very late in addressing the issue of introducing into the curriculum of general schools practical classes in machine science, electrical engineering and the foundations of agriculture. I. P. Lvov also stressed that the resolution stated that less time was spent on art and moral education in the curriculum, and it follows that at that time there was no need to develop spiritual education in the younger generation [3].

I. P. Lvov analyzed point by point the resolution of I. A. Kairov "On the state of pedagogical science and measures to eliminate its backlog" and agreed with the tasks set by the Academy of Pedagogical Sciences before educational institutions, the Ministry of Public Education, namely: a comprehensive creative study of scientific workers of pedagogics classics on upbringing and education, which should be the main task of solving all pedagogical issues.

Of course, I. P. Lvov showed the prospects for the resolution, consisted in drawing attention to topical issues of teaching pedagogical disciplines, scientific development of theoretical textbooks on pedagogy, history of pedagogy and psychology. I. P. Lvov supported the decision on the preparation of monographs from the main branches of pedagogy, history of pedagogy, organization, practical and theoretical studies, management of educational work in educational institutions. The Academy was supposed to help Ukrainian families better educate their children by printing a series of postcards and brochures on topical issues of family education and to prepare the book "A Practical Guide for Parents". Pedagogical psychology was to be developed not only in the system of psychology, but also in the system of pedagogy with the actual topics of the time [3].

I. P. Lvov supported the proposal of the Academy of Pedagogical Sciences to hold creative events on topical issues of pedagogy; discussion of the textbook on pedagogy V. G. Shimbereva, D. A. Ogorodnikova; publications in the magazine "Ezhegodnik" at the Academy of Pedagogical Sciences of short references on the dissertations of scientists [3].

On behalf of I. P. Lvov, some provisions of I. A. Kairov's resolution "On the state of pedagogical science and measures to eliminate its backwardness" were introduced in practice. In particular, methods for eliminating disadvantages and solving pedagogical problems those were set before state school and the Ministry of Education of the XIXth Congress. At the department of pedagogy has indepth studied the works of classical pedagogues in order to learn the best indications of realization teaching and research work in educational institutions. Improved at the department of pedagogy and other departments a healthy creative critique and self-criticism in reasonable ethical and pedagogical rules (this applies to recommendations for reviews, sections of scientific papers and methodological work of teachers at the departments of the Chernihiv pedagogical Institute). They made innovations in teaching pedagogy at various faculties of the institute; Some pedagogical techniques were studied extensively in psychology (subject) and vice versa, psychology directions were taught in lectures on pedagogy in more detail; established a working connection of the Chernihiv Pedagogical Institute with schools, introduced teachers of schools with the work of teachers of pedagogical disciplines. This facilitated the selection of important topics for research activities on pedagogical issues, since practice is the basis of skilled pedagogical personnel.

1. All teachers of the Chernihiv pedagogical Institute were supposed to write scientific papers concerning school questions and tasks.

2. Teachers of the Chernihiv pedagogical Institute that offered a choice of topical topics and specific guidelines for scientific work and pedagogical experiments should contact the Republican Research Institute of Pedagogy and Psychology.

3. Included in the research work of individual teachers who shared valuable material from their teaching experience and participated in the experiments.

I.P. Lvov noted the need to hold joint meetings at the Department of Pedagogy and Psychology every 2-3 months, discussing new problems of the pedagogical psychological direction [3].

Conclusions. I. P. Lvov, as head of the pedagogical department of the Chernihiv Pedagogical Institute, proved himself a talented teacher, intelligent and fair leader, his respected and revered his pupils, students and colleagues. His management achievements in educational institutions and institutions of higher education should be used by young leaders and teachers to improve the organization of training and education of students in order to develop their individuality without violating the laws of nature.

\section{References}

1. O sostoyanii pedagogicheskoy nauki i merah likvidatsii ee otstavaniya rezolyutsiya po dokladu prezidenta Akademii pedagogicheskih nauk RSFSR by I. A. Kairova na soveschanii po voprosam pedagogiki i plan meropriyatiy APN $v$ svyazi s zadachami, vyidvinutyimi soveschaniem; doklad zaveduyuschego kafedroy pedagogiki Chernigovskogo pedinstituta dotsenta Lvova I. P. na zasedanii Soveta instituta po obsuzhdeniyu etih dokumentov (1955). [On the state of pedagogical science and measures to eliminate its backwardness - resolution on the report of president of the Academy of Pedagogical Sciences of the RSFSR I. A. Kairova at a meeting on pedagogy and the plan of activities of the APN in connection with the tasks put forward by the meeting: Report of the Head of the department of pedagogy of the Chernigov pedagogical institute, associate professor Lvov I. P. at a meeting of the Council of the Institute to discuss these documents], DACHO Ukraine, f. R-1495, op. I. sp., 10, 32.

2. Plan rabotyi kafedryi pedagogiki Chernigovskogo uchitelskogo instituta na II semestr 1950-1951 uchebnogo goda i rabotyi v bazovoy shkole na I polugodie 1952-1953 uchebnogo goda (1950-1953). [Work plan of the department of pedagogy of the Chernigov Teacher's Institute for the second semester of the 1950-1951 academic year and work in the basic school for 
the first half of the 1952-1953 school year (1950-1953)], DACHO Ukraine, $\mathrm{f}$. R-1495, op. I. sp., 12, 4

3. Otchet o provedenii gosudarstvennyih vyipusknyih ekzamenov po zaochnomu otdeleniyu russkogo yazyika i literaturyi Chernigovskogo uchitelskogo instituta (1955), [Report of the state final examinations in the correspondence department of Russian language and literature of the Chernigov Teachers' Institute] DACHO Ukraine, f. R-1495, op. I. sp., 17, 20

4. Plan rabotyi kafedryi pedagogiki Chernigovskogo uchitelskogo instituta na II semestr 1950-1951 uchebnogo goda i rabotyi v bazovoy shkole na I polugodie 1952-1953 uchebnogo goda (1950-1953). [Work plan of the department of pedagogy of the Chernigov Teacher's Institute for the second semester of the 1950-1951 academic year and work in the basic school for the first half of the 1952-1953 school year (1950-1953)], DACHO Ukraine, f. R-1495, op. I. sp., 12, 4

5. Informatsionnaya zapiska zaveduyuschego kafedroy pedagogiki Chernigovskogo uchitelskogo instituta Lvova I. P. o podgotovke kafedryi k novomu uchebnomu godu $v$ svyazi $s$ zamechaniyami komissii, obsledovannoy rabotyi kafedryi (1950). [Information note of the head of department of pedagogy of the Chernigov Teachers' Institute by Lviv I. P. about preparation of the department for a new academic year in connection with the observations of the commission, inspected work of the department],DACHO Ukraine, f. R-1495, op. I. sp., 14, 8.

6. Godovoy otchet o rabote kafedryi pedagogiki Chernigovskogo uchitelskogo instituta za 1951/52 uchebnoy god, sostavlenyiy Lvovom I. P. (1952). [Annual report about a work of the Department of Pedagogy in Chernigov Teachers' Institute for the 1951/52 academic year, compiled by Lvov I. P. (1952)], DACHO Ukraine, f. R-1495, op. I. sp., 15, 26.

7. Godovoy otchet o rabote kafedryi pedagogiki Chernigovskogo uchitelskogo instituta za 1952/1953 uchebnyiy god. Sostavlennyiy Lvovom I. P. (1953). [Annual report about a work of the Department of Pedagogy in Chernigov Teachers' Institute for the 1952/1953 academic year, compiled by Lvov I. P. (1953)],DACHO Ukraine, f. R-1495, op. I. sp., 16, 63.

8. Svidetelstvo o rozhdenii, avtobiografiya i lichnle listki Lvova I.P., Certificate of birth, autobiography and personal documents by I. P. Lvov. DACHO Ukraine, f. R-1495, op Isp., 1, 54

Надійшла до редколегії 13.06.19

А. Остапенко, асп.

Київський національний університет імені Тараса Шевченка, Київ, Україна

\section{ОРГАНІЗАЦІЙНО-ПЕДАГОГІЧНА ДІЯЛЬНІСТЬ І. П. ЛЬВОВА}

Стаття описує діяльність І. П. Львова як завідувача кафедри педагогіки Чернігівського педагогічного інституту.

Було вивчено рукописну працю вчителя при проведення державних іспитів, проаналізовано щорічні звіти кафедри педагогіки, складені І.П. Львовим за 1950-1951,1951-1952,1952-1953 навчальний рік, плани кафедри та план заняття зі студентами 2 курсу, українськими та російськими кафедрами гуманітарного факультету.

Особисті якості вчителя були проаналізовані в кількох архівних документах. Це показало, що І. П. Львів був мудрим викладачем і морально чесним до студентів та колег, творчим для підтримки кафедри педагогіки, а також лабораторії психології при ній усім необхідним обладнанням для самостійної освіти студентів. Він презентував новаторські педагогічні ідеї та впровадив їх у педагогічний процес кафедри педагогіки.

І. П. Львів взяв на себе ініціативу щодо реалізації навчальних заходів серед учнів, таких як доповіді, лекції про плани органів народної освіти, органів шкільної освіти, шкільної адміністрації, батьківських комітетів та керівництва педагогічних гуртків.

І. П. Львів вважав за необхідне, щоб викладачі інституту читали популярні лекції батькам студентів. Студенти інституту мали долучитися до роботи класних керівників, проводити з учнями різні види аудиторних та позакласних заходів.

Проаналізовано звіт про навчально-методичну роботу кафедри педагогіки На кафедрі педагогіки під керівництвом І. П. Львова робочі навчальні програми з усіх дисциплін кафедри були своєчасно заслухані на регулярних засіданнях. І. П. Львів у звіті вказав позитивні моменти щодо навчальної діяльності, яку проводили протягом навчального року викладачі кафедри педагогіки щодо зміни робочих планів кафедри.

Ключові слова: І. П. Львів, план роботи для занять, план роботи кафедри педагогіки, щорічний звіт.

UDC 37(09)(477.4/7)

O. Plakhotnik, Doctor of Pedagogical Sciences, Professor Taras Shevchenko National University of Kyiv, Kyiv, Ukraine

\section{PROFESSIONALLY-PEDAGOGICAL PREPARATION OF TEACHERS OF PUBLIC SCHOOLS IN TEACHING SEMINARIES OF UKRAINE}

The article deals with the analysis of professionally-pedagogical preparation of teachers of public schools of teaching seminaries of Ukraine, that can become valuable acquisition for professional preparation of specialists of the modern system of pedagogical education. An important accent have been done on history, forming of maintenance and principles of professional preparation of teachers of public schools in teaching seminaries. The article analyzes the tendency of instability and relative unsystematic of preparation of teachers registers for public schools, that partly predetermined by educational reforms in industry of primary education. It has been proved that requirement to semantic part of professional preparation of teacher of public school were in direct dependence on a social order on the level of its qualification. The general preparation of future teacher was limited, at the same time professionally pedagogical preparation was in the comparatively best state.

The future teachers of public schools often have been studied German classic pedagogics, and educational practice rendered substantial influence on the level of professional preparedness of future teachers of public schools.

Keywords: professional preparation of teacher, public schools, teaching seminary, maintenance of education, principle of education, pedagogical practice.

Formulation of the problem. Preparation of skilled teacher is one of the major scientific, technical and practically professional problems, on the decision of which success of alteration of the system of education depends in a country. The basic objectives of pedagogical educational establishments is realization of high-quality professional preparation of teacher which corresponds to the modern requirements of studies and education of young people. According to the features of the modern stage and prospects of development of pedagogical education there is reformation of maintenance of preparation of future teachers; new requirements are formed to their professional competence; new specialties are introduced, methodology and technology training have been updated. Historical experience of development of pedagogical education didn't lose its significance today. Experience of preparation of teachers of public schools can be important for professional preparation of specialists of modern system of pedagogical education.

Analysis of recent researches and publications. Historical and pedagogical analysis of the development of professional training of future teachers interested many Ukrainian scientists-teachers. In particular, V. Velichkina, N. Demyanenko, I. Kolesnik, T. Stolyarchuk and others. They studied the issues of teacher training in Ukraine in the 19th the first half of the 20th century, and its activities in public schools; A. Arseniev, N. Zikiev, M. Kuzmin and others studied 
the problems of organization the educational process in the teacher's seminaries; the formation of a national school in Ukraine became the subject of study of N. Kalenichenko, M. Stelmakhovich, B. Stuparik, M. Yarmachenko and others; the development of professional pedagogical education, including the Higher Education, studied V. Maiboroda, F. Panachina and others.

Research presentation. According to research by scientists of the 19th and 20th centuries, teaching seminaries have become an organizational and professional basis for the staffing of popular schools. Many progressive native teachers and publicists devoted their works to the study of the literacy of peasants. Well-known teachers-scientists of the end of 19th - the beginning of 20th centuries have been formulated many theoretical positions about the necessity of methodical and practical pedagogical preparations of teacher. Well-known teachers (S. Vasilchenko, B. Grinchenko, M. Korf, T. Lubenets and others) themselves worked as teachers in public schools. The works of M. Drahomanov, M. Korf, K. Ushinsky and other prominent teachers of the second half of the 19th and the beginning of 20th centuries have been described the significant interest in the study of this problem. They proved the necessity of scientific and practical training of the teacher, considering it as the unity of three main areas: general education, general pedagogical and practical area.

In the teachers' seminaries of Ukraine in the second half of the 19th and early 20 th centuries, there were the content of teacher training that was directed at the appropriate time for a social order and provided students with elementary knowledge of teaching methods and fragmentary pedagogical skills. Thus, in the seminaries a course of pedagogy was taught, which included the history of pedagogy. Seminarists studied elements of the theory of education, principles and methods of teaching. Particular attention was done the study of foreign pedagogy, first of all, the German pedagogical theories of J. Pesalotzzi, F. Frebel, A. Distervega. The great attention of teachers in studying the course of pedagogy was given to the assimilation of the principles of teaching by future teachers. In the programs of pedagogy and methodological recommendations of the teachers who compiled these programs, we can find almost all the principles of learning, known today. The principle of the nature of the correspondence of the organization of learning ("Educate according to nature"; "Take into account the natural stages of human development; apply the physical and mental activities of the student, the game, the imagination and the ability to observe; use such subjects as tales, biographies, amazing features of famous people and biblical stories"; "Educate in the students the ideas, thoughts and aspirations of the educated person, a true citizen of their country."). The principle of continuity and prospects ("Start teaching from the point at which the student is, show condition the knowledge of the student before the beginning of teaching, avoid retraining, but apply gradualness and continuity of lessons; teach as little as possible but thoroughly; repeat the subject while studying; avoid mixed concepts and do not make ready conclusions for the student"). The principle of systematic learning ("Go from near to far, from easy to complex, from the known to the unknown, teach elementary, not scientific or dogmatic way"; "Try to achieve that the pupils remember everything they learned; repeat the previous material, discuss the content of the proclamations, songs and poems, and develop the memory of children"). Principle of visibility ("It is necessary to teach clearly, this rule is the basis of any education of children and young people; start teaching the subject from the fact, not the principle"). Principles of accessibility ("Do not teach what the student can not understand, the truth that is learned, but not understood, is harmful; cheer and desire to learn are a sign of understanding; laziness and apathy are born due to misunderstanding of the case...). Teach available, so that the student could himself tell what he learned. "The principle of individualization and differentiation of learning ("Take into account the personality of the student, his individual characteristics, preserve innate abilities and talents of the disciples") [12, p. 32-34].

In periodicals of that time, sometimes the articles appeared related to some aspects of the organization of the educational process, for example, the schedule of classes. In colleges, the schedule of classes was based on the principle from more complex subjects to simpler ones. For example, mathematics was a more complex subject and had to be included in the schedule by the first lesson, and singing as a simpler subject was the last. Such a division of objects according to the degree of their complexity caused ambiguous evaluation. Some authors believed that the complexity of the subject is very categorical for some children, mathematics may be a simpler subject than singing, and vice versa. Particular attention was paid to the style of behavior and clothes of the teacher, referring to the associative perception of the child what more pleasant impression of student about a teacher, the more persons interested he studies [7, p. 77].

In their articles in the periodical press, some educators drew the attention of the public to the importance of a deeper study of individual subjects, such as, for example, mathematics and science. They noted that the future folk teacher had to possess them fully in order to be able to teach them at school. With regard to natural science, it was worth teaching children to listen to nature, be able to observe it, noticing everyday phenomena of the natural environment [5, p. 163].

It is known that the course of teaching in the teacher's seminaries lasted three years and was too short in order to provide the seminarians with general and special training. The main task of the teachers' seminaries was religious education, which contributed to the formation of the personality of the national teacher in the spirit of obedience and devotion to the throne and church. Estimating the content of education in the teaching seminary, Andriychuk N. distinguishes such semantic blocks in it: a) social and spiritual: theology, sacred history, catechidology, national history; b) linguistic: Russian and Church Slavonic languages; c) natural sciences: geography, natural sciences, mathematics; d) special: the history of pedagogy, the methodology of initial education [1, p. 153].

In the 1878 - 1879 academic year among the subjects studied by the seminarians were: Russian, Church Slavonic, history, arithmetic, geometry, the doctrine of worship, kathazis, sacred history, national history, geography, natural history, the history of pedagogy and the methodology of elementary education. The curricula of all these subjects were composed by teachers of seminaries. The teacher of the subject "The Law of God" compiled a program of three subjects: "Law of God", kathazis and sacred history. The teacher also participated in the development of a curriculum on national history. Teachers' Seminaries were provided with some pedagogical journals and manuals: "Folk School", "Family Evenings", a collection of children's songs and dance games, school gymnastics, a map of sacred history. Such educational methodology helped teachers to create curricula for subjects taught in the seminary [6, p. 9-10].

The subject of sacred history was the actual study of the Bible. The program on this subject covered all major events related to the Holy Scriptures. The program of the national history included the question of studying by the seminarians 